\title{
Nitrogen Fixation in Klebsiella pneumoniae: Nitrogenase Levels and the Effect of Added Molybdate on Nitrogenase Derepressed under Molybdenum Deprivation
}

\author{
By DANIEL KAHN, $†$ MARIE HAWKINS AND ROBERT R. EADY* \\ A.R.C. Unit of Nitrogen Fixation, University of Sussex, Brighton BN1 9RQ,U.K.
}

(Received 10 June 1981; revised 6 August 1981)

\begin{abstract}
Klebsiella pneumoniae had low levels of nitrogenase activity and antigenic cross-reacting material to both nitrogenase components when grown, or when the nif operons were derepressed, under Mo-deficient conditions. When molybdate $(100 \mu \mathrm{M})$ was added to Mo-deprived cultures shortly after initiating derepression of nitrogenase, activity was rapidly restored and reached up to $60 \%$ of that of control cultures supplied with molybdate throughout derepression. Restoration of activity was prevented by chloramphenicol $\left(200 \mu \mathrm{g} \mathrm{ml}^{-1}\right)$ but not by tetracycline $\left(100 \mu \mathrm{g} \mathrm{ml}^{-1}\right)$, although both compounds inhibited general protein synthesis at these concentrations. Expression of the nif structural genes was not rapidly stimulated by added molybdate, so the rapid stimulation of activity was due to the activation of a low level of apoprotein present in Mo-deprived cultures. After $16 \mathrm{~h}$ of Mo-deprivation, suspensions no longer responded rapidly to added molybdate, consistent with the finding that, when further protein synthesis was inhibited by the addition of chloramphenicol after $4 \mathrm{~h}$ Modeprivation, polypeptides of the MoFe protein $(\mathrm{Kp} 1)$ but not the Fe protein $(\mathrm{Kp} 2)$ of nitrogenase were degraded within the following $18 \mathrm{~h}$.
\end{abstract}

\section{INTRODUCTION}

Biological $\mathrm{N}_{2}$ fixation is an energy-dependent process requiring ATP and a source of lowpotential reducing equivalents. About $16 \mathrm{~mol} \mathrm{ATP}$ are consumed per mol $\mathrm{N}_{2}$ fixed in vivo (for a review, see Andersen et al., 1977). In view of this high energy requirement it is not surprising that nitrogenase is repressed when organisms have a plentiful supply of fixed $\mathrm{N}$, or when this $\mathrm{O}_{2}$-sensitive enzyme system would be inactivated by free dissolved $\mathrm{O}_{2}$ (Eady et al., 1978; Robson, 1979).

The presence of molybdenum in the MoFe protein of nitrogenase (see Eady \& Smith, 1979) explains the long-known essential requirement for Mo in biological $\mathrm{N}_{2}$ fixation (Bortels, 1930). Speculation that Mo may regulate nitrogenase synthesis has led to studies of the effect of Mo-deprivation on nitrogenase in a number of organisms, and no uniform response has been found: the cyanobacteria Plectonema boryanum and Anabaena cylindrica synthesize both the $\mathrm{Fe}$ protein and the MoFe protein of nitrogenase (Nagatani \& Haselkorn, 1978; Hallenbeck \& Benemann, 1980); Azotobacter vinelandii synthesizes only the $\mathrm{Fe}$ protein (Nagatani \& Brill, 1974); Clostridium pasteurianum synthesizes neither component (Cardenas \& Mortenson, 1975). For Klebsiella pneumoniae there are conflicting data concerning the involvement of molybdate in nitrogenase synthesis. Since only low levels of antigenic cross-reacting material to either nitrogenase component were detected under Mo-deprived conditions, Brill et al. (1974) concluded that molybdate was required for nitrogenase synthesis. However, Kennedy \& Postgate (1977) detected significant levels of

† Present address: Station de Pathologie Végétale CNRA, Etoile de Choisy, Route de Saint-Cyr, 78000 Versailles, France. 
nitrogenase polypeptides by sodium dodecyl sulphate (SDS) gel electrophoresis of extracts of a narD strain of Escherichia coli carrying the Klebsiella $\mathrm{N}_{2}$ fixation (nif) gene cluster on the plasmid pRD1; this strain was deficient in Mo-processing (Sperl \& DeMoss, 1975) and consequently the nitrogenase was inactive unless a sufficiently high concentration of molybdate (which relieved the $\mathrm{Nar}^{-}$phenotype) was subsequently supplied. Experiments using gene fusions in which the lacZ gene was under the control of various promoters of the K. pneumoniae nif gene cluster (Dixon et al., 1980) indicated that none of the nif operons had an absolute requirement for molybdate for expression, but that full expression of the structural genes (as determined from measurement of $\beta$-galactosidase activity) required the presence of molybdate together with another nif-encoded polypeptide.

In this paper we report a reinvestigation of the involvement of molybdate in regulating nitrogenase synthesis in $K$. pneumoniae, using immunochemical and ${ }^{14} \mathrm{C}$ pulse-labelling techniques to determine nitrogenase levels directly. In addition, data are presented on the effects of chloramphenicol and tetracycline on the ability of molybdate to restore nitrogenase activity to Mo-deprived organisms. A preliminary report of some of this work was given by Postgate et al. (1981).

\section{METHODS}

Organisms and culture. The Klebsiella pneumoniae strains used in this work were the wild-type strain M5a1, and strain UNF619(pMF183), a nif $^{+} \Delta l a c /$ nifH2783::Mud(Aplac) merodiploid (Dixon et al., 1980), which carries the lac $Z$ gene (encoding $\beta$-galactosidase) fused in the structural gene (nifH) of $\mathrm{Kp} 2$. The stock strains were maintained at $20^{\circ} \mathrm{C}$ in air on $2 \%(\mathrm{w} / \mathrm{v})$ nutrient agar slopes and subcultured at 2 month intervals. Cultures were grown anaerobically at $30^{\circ} \mathrm{C}$ in N-free medium (NFDM; Cannon et al., 1974) supplemented with $\left(\mathrm{NH}_{4}\right)_{2} \mathrm{SO}_{4}\left(1.5 \mathrm{mg} \mathrm{ml}^{-1}\right)$ to repress nitrogenase synthesis. Traces of $\mathrm{Mo}$ in the medium were removed by extraction of the glucose and sodium and potassium phosphates with 8-hydroxyquinoline and chloroform (Kelly \& Lang, 1970), and by washing glassware with nitric acid (50\%, v/v, AnalaR). Organisms were collected by centrifuging and resuspended under $\mathrm{Ar}$ in Mo-depleted NFDM without added $\mathrm{NH}_{4}^{+}$but containing aspartate $\left(100 \mu \mathrm{g} \mathrm{ml}^{-1}\right)$. Nitrogenase activity was derepressed at $30^{\circ} \mathrm{C}$ with or without sodium molybdate $(100 \mu \mathrm{M})$ or sodium tungstate $(100 \mu \mathrm{M})$ as indicated.

Radioactive labelling. Samples $(1 \mathrm{ml})$ were pulse-labelled with a mixture of ${ }^{14} \mathrm{C}$-labelled amino acids essentially as described by Eady et al. (1978). Uptake of radioactivity was stopped after $5 \mathrm{~min}$ by addition of $0.15 \mathrm{ml}$ of unlabelled Difco Casamino acids $(2 \mathrm{mg})$ and $0.15 \mathrm{ml}$ of phenylmethylsulphonyl fluoride in 2-propanol $(0.3 \mathrm{mg})$. The saline washing step of Eady et al. (1978) was omitted and the samples were stored on ice before the organisms were harvested by centrifuging.

Electrophoresis and autoradiography. The pelleted organisms were resuspended in $0.2 \mathrm{ml}$ of Ortec sample buffer (Eady et al., 1978) and lysed by heating in a boiling water bath for $4 \mathrm{~min}$. Polyacrylamide gels containing $10 \%(w / v)$ acrylamide and $0.16 \%(w / v)$ bisacrylamide were loaded with samples containing approximately 40000 c.p.m. Electrophoresis was carried out as described by Kennedy et al. (1976), and autoradiography of the dried gels and scanning of the X-ray films as described by Eady et al. (1978). To determine the relative rates of synthesis of $\mathrm{Kp} 1$ and $\mathrm{Kp2}$, the relevant peaks were cut out and their weights expressed as a percentage of that of the complete scan (Eady et al., 1978).

Protein synthesis. The effectiveness of chloramphenicol and tetracycline in preventing general protein synthesis was checked by their ability to inhibit incorporation of ${ }^{14} \mathrm{C}$-labelled amino acids into trichloroacetic acidprecipitable material. Derepressing cultures were treated with chloramphenicol $\left(200 \mu \mathrm{g} \mathrm{ml}^{-1}\right)$ or tetracycline $\left(100 \mu \mathrm{g} \mathrm{m}^{-1}\right)$. At intervals samples were removed, pulse-labelled for $1 \mathrm{~min}$, and lysed with sample buffer as described above. Samples $(5 \mu \mathrm{l})$ of the lysates were added to $1 \mathrm{ml}$ of carrier bovine serum albumin $(100 \mu \mathrm{g})$ before precipitation with $1 \mathrm{ml}$ of $10 \%(\mathrm{w} / \mathrm{v})$ trichloroacetic acid. The precipitate was collected by filtration, washed with $5 \%(\mathrm{w} / \mathrm{v})$ trichloroacetic acid and, after drying, the radioactivity was determined by scintillation counting.

Enzyme assays. Nitrogenase activity was measured in cultures ( 1 or $2 \mathrm{ml}$ containing approx. $0.2 \mathrm{mg}$ protein $\mathrm{ml}^{-1}$ ) in conical flasks $(25 \mathrm{ml}$ nominal volume) capped with a rubber closure (Suba-seal) and maintained under Ar containing $10 \%(\mathrm{v} / \mathrm{v})$ acetylene. The flasks were shaken in a water bath at $30^{\circ} \mathrm{C}$ and at intervals gas samples $(0.5 \mathrm{ml})$ were removed by syringe for measurement by g.l.c. of the ethylene formed. Specific activities were calculated from the increment in ethylene between samples, using the acetylene peak as an internal standard. Nitrogenase activity in crude extracts was measured as described by Eady $e t$ al. (1972). The maximum potential activity of the individual nitrogenase components $\mathrm{Kp} 1$ and $\mathrm{Kp} 2$ in extracts was measured by the addition of purified $\mathrm{Kp} 2$ or $\mathrm{Kp} 1$, respectively, to the assay.

$\beta$-Galactosidase activity was measured as described by Dixon et al. (1980) under the same conditions as 
above except that acetylene was omitted. One unit of activity is defined as the amount of enzyme that will hydrolyse $1 \mathrm{nmol} o$-nitrophenyl- $\beta$-D-galactoside $\mathrm{min}^{-1}$ at $30^{\circ} \mathrm{C}$.

Nomenclature. Nitrogenase is comprised of two redox proteins one of which contains both $\mathrm{Fe}$ and $\mathrm{Mo}$, and one which contains only $\mathrm{Fe}$ (see Eady \& Smith, 1979). The nomenclature used in this paper for the $K$. pneumoniae proteins is as follows: the MoFe protein (Kpl) is an $\alpha_{2} \beta_{2}$ tetramer, the subunits of which are encoded by nifD and nifK respectively; the Fe protein $(\mathrm{Kp} 2)$ is a dimer, the subunit of which is encoded by nifH (Roberts et al., 1978).

Serological assay. $\mathrm{Kp} 1$ and $\mathrm{Kp} 2$ proteins, purified by repetitive $\left(\mathrm{NH}_{4}\right)_{2} \mathrm{SO}_{4}$ precipitation (Rennie et al., 1978), were used as antigens to induce specific antibody formation in New Zealand rabbits. Quantification of antibody cross-reacting material present in crude extracts was performed by the Laurell immunoelectrophoresis technique (Laurell, 1972), using calibration curves prepared from dilutions of antigens of known concentrations. Linear precipitin cones were obtained up to $3 \mu \mathrm{g} \mathrm{Kp} 1$ and $0.5 \mu \mathrm{g} \mathrm{Kp} 2$.

\section{RES ULTS}

\section{Nitrogenase levels in Mo-deprived organisms}

Both the nitrogenase activity of extracts of organisms supplied with molybdate throughout derepression, and the maximum potential $\mathrm{Kp} 2$ activity, were comparable with nitrogenase activity in vivo. The maximum potential $\mathrm{Kp} 1$ activity, as determined with saturating amounts of $\mathrm{Kp} 2$, was approximately 3 -fold higher than the nitrogenase activity of unsupplemented extracts (Table 1). The concentration of active $\mathrm{Kp} 2$ was therefore rate-limiting for nitrogenase activity of extracts.

Typically, the specific activity of nitrogenase after $7 \mathrm{~h}$ derepression under conditions of Mo-deprivation was approximately $2 \%$ of that of cultures supplied with molybdate throughout derepression (Fig. 1). In extracts prepared from Mo-deprived organisms, Kp1 activity was approximately $3 \%$ of that in extracts of cultures supplied with molybdate, and no Kp2 activity was detected (Table 1). Rocket immunoelectrophoresis of extracts after $6 \mathrm{~h}$ derepression under Mo-deprived conditions showed that the levels of cross-reacting materials to both anti-Kp1 and anti-Kp2 were considerably lower than in control suspensions (Table 1). After $16 \mathrm{~h}$ under non-repressive but Mo-deprived conditions, the levels of cross-reacting material to both anti-Kp1 and anti-Kp2 were reduced to the limit of detection. The addition of tungstate $(100 \mu \mathrm{M})$ in the Mo-deficient medium did not significantly alter the nitrogenase activity or the levels of cross-reacting material. Consistent with these serological data, extracts of $18 \mathrm{~h}$ Mo-deprived suspensions showed neither $\mathrm{Kp} 1$ nor $\mathrm{Kp} 2$ bands in stained SDS polyacrylamide electrophoresis gels.

\section{Table 1. Effects of Mo-deprivation on nitrogenase activity and levels of antigenic cross- reacting material to nitrogenase components in extracts of $K$. pneumoniae}

$\mathrm{NH}_{4}^{+}$-grown cultures were harvested and derepressed for $6 \mathrm{~h}$ in Mo-deficient medium with the additions indicated $(100 \mu \mathrm{M})$. The nitrogenase activity in vivo was then determined, before the suspensions were harvested by centrifuging and extracts were prepared by disruption in a French pressure cell. The protein concentrations of the extracts were, respectively, $7.7,8.8$ and $7.7 \mathrm{mg} \mathrm{ml}^{-1}$ for organisms derepressed in medium containing molybdate, tungstate and no addition; the $100 \%$ values correspond to $0.44 \mathrm{mg} \mathrm{ml}^{-1}$ for $\mathrm{Kp} 1$ and $0.38 \mathrm{mg} \mathrm{ml}^{-1}$ for $\mathrm{Kp} 2$, determined by immunoelectrophoresis. The nitrogenase activity was measured both in the normal extract (the intrinsic activity) and after the addition of purified $\mathrm{Kp} 1$ or $\mathrm{Kp} 2$ protein to assess the maximum potential activity of nitrogenase components $\mathrm{Kp} 2$ and $\mathrm{Kp} 1$, respectively.

\begin{tabular}{|c|c|c|c|c|c|c|}
\hline \multirow{3}{*}{$\begin{array}{l}\text { Addition to } \\
\text { Mo-deficient } \\
\text { NFDM }\end{array}$} & \multirow{2}{*}{\multicolumn{2}{|c|}{$\begin{array}{c}\text { Antigenic cross-reacting } \\
\text { material }\end{array}$}} & \multicolumn{4}{|c|}{$\begin{array}{c}\text { Nitrogenase activity } \\
\left.\text { [nmol ethylene formed } \min ^{-1}(\mathrm{mg} \text { protein })^{-1}\right]\end{array}$} \\
\hline & & & \multirow[b]{2}{*}{ Cultures } & \multicolumn{3}{|c|}{ Extracts } \\
\hline & $\begin{array}{l}\mathrm{Kp} 1 \\
(\%)\end{array}$ & $\begin{array}{r}\mathrm{Kp} 2 \\
(\%)\end{array}$ & & $\begin{array}{l}\text { Intrinsic } \\
\text { activity }\end{array}$ & $\underset{\text { activity }}{\text { Maximum } \mathrm{Kp} 2}$ & $\begin{array}{l}\text { Maximum Kp1 } \\
\text { activity }\end{array}$ \\
\hline Molybdate & 100 & 100 & 14 & $17 \cdot 5$ & $18 \cdot 9$ & $48 \cdot 7$ \\
\hline Tungstate & $3 \cdot 6$ & 13.7 & 0.4 & 0 & 0 & 1 \\
\hline None & 3.6 & $10 \cdot 5$ & 0.35 & 0 & 0 & $1 \cdot 5$ \\
\hline
\end{tabular}




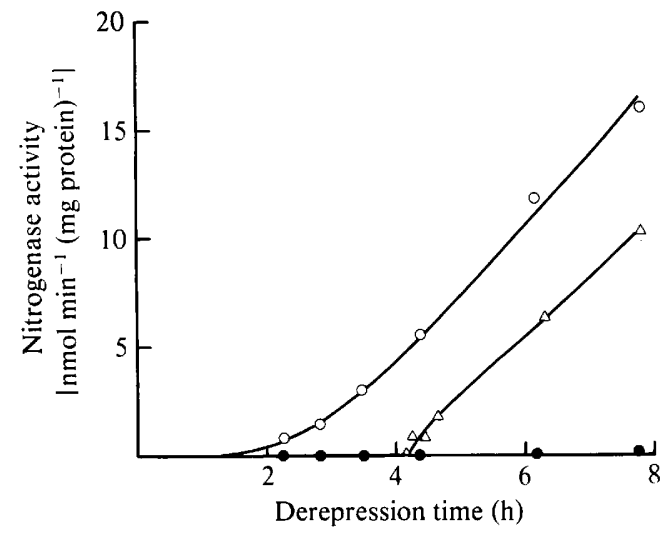

Fig. 1

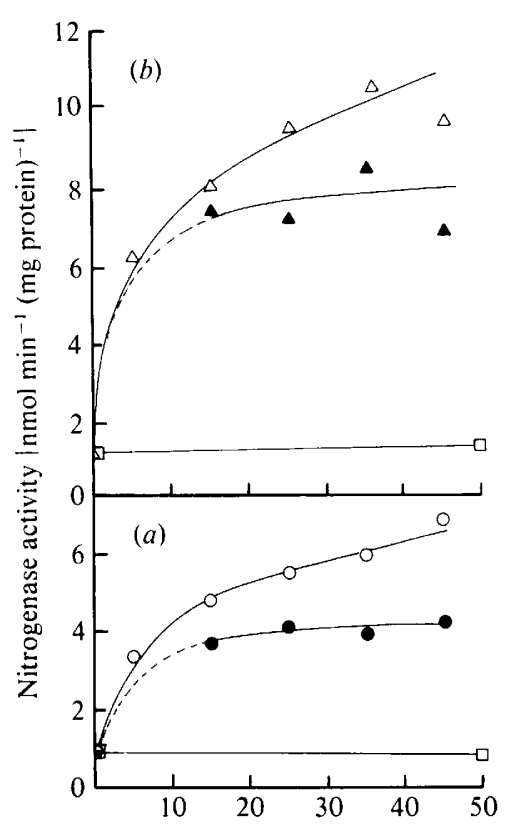

Time after molybdate addition $(\mathrm{min})$

Fig. 2

Fig. 1. Effect of Mo-deprivation on derepression of nitrogenase activity, and the restoration of activity by added molybdate. $\mathrm{NH}_{4}^{+}$-grown organisms were resuspended in NFDM containing aspartate $\left(100 \mu \mathrm{g} \mathrm{ml}^{-1}\right)$ with or without added molybdate $(100 \mu \mathrm{M})$. The gas phase was Ar containing acetylene $(10 \%, v / v)$, and gas samples were removed at intervals for measurement of nitrogenase activity [expressed as nmol ethylene formed $\min ^{-1}(\mathrm{mg} \text { protein })^{-1}$ ]: $\mathrm{O}$, molybdate present throughout derepression; $\triangle$, molybdate added after $4 \mathrm{~h} 10 \mathrm{~min}$ derepression; $\boldsymbol{O}$, no added molybdate.

Fig. 2. Effect of tetracycline on the restoration of nitrogenase activity by added molybdate. Cultures were derepressed under Mo-deprived conditions for $4 \mathrm{~h}(a)$ or $6 \mathrm{~h}(b)$. Where indicated, tetracycline $\left(100 \mu \mathrm{g} \mathrm{m}^{-1}\right)$ was then added, followed $5 \mathrm{~min}$ later (zero time) by molybdate $(100 \mu \mathrm{M})$. Samples were taken at intervals during the following $50 \mathrm{~min}$ for determination of nitrogenase activity [expressed as nmol ethylene formed $\left.\min ^{-1}(\mathrm{mg} \text { protein })^{-1}\right]: 0, \triangle$, molybdate added at zero time (no tetracycline); $\boldsymbol{\Delta}, \Delta$, tetracycline added $5 \mathrm{~min}$ before molybdate; $\square$, no added molybdate or tetracycline (control). The dotted curves are corrected for the contribution of newly-synthesized nitrogenase to the observed activity by subtraction of the linear rate of increase which occurs in the absence of tetracycline.

\section{Effect of molybdate on nitrogenase activity in Mo-deprived cultures}

When molybdate $(100 \mu \mathrm{M})$ was added to Mo-deprived organisms soon after derepression had been detected in control Mo-sufficient suspensions, nitrogenase activity was rapidly restored (Fig. 1) yet the levels of cross-reacting material to both anti-Kp1 and anti-Kp2 remained unchanged for at least $45 \mathrm{~min}$. The response was biphasic, with a rapid burst followed by a slower increase in activity (Fig. 2). The initial increase was at least 10 times faster than the rate of derepression of activity in control suspensions.

In contrast, prolonged Mo-deprivation resulted in the loss of the ability to respond rapidly to added molybdate. Cultures grown for $16 \mathrm{~h}$ under Mo-deprivation with aspartate, a nonrepressive $\mathrm{N}$ source, showed a $50 \mathrm{~min}$ lag following addition of molybdate before nitrogenase activity gradually increased.

The rapid increase in nitrogenase activity following addition of molybdate could arise either from the activation of $\mathrm{Kp} 1$ apoprotein synthesized by the organisms during Modeprivation or by stimulation of transcription or translation of the nif structural genes, these being the only genes of the nif cluster whose expression responds to added molybdate (Dixon et al., 1980). These two alternatives were investigated further. 


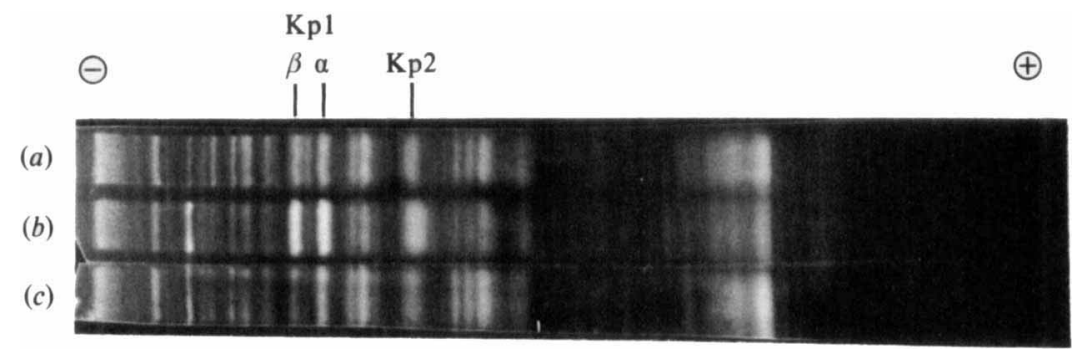

Fig. 3. Effect of molybdate and tungstate on the rate of nitrogenase synthesis by $K$. pneumoniae M5a 1 during derepression of nif. An $\mathrm{NH}_{4}^{+}$-grown culture of $K$. pneumoniae was harvested and resuspended in Mo-depleted NFDM with the following additions at $100 \mu \mathrm{M}$ : $(a)$ none; $(b)$ molybdate; $(c)$ tungstate. After $5 \mathrm{~h} 45 \mathrm{~min}$ derepression, suspensions were pulse-labelled for $5 \mathrm{~min}$ with a mixture of ${ }^{14} \mathrm{C}$ labelled amino acids. Labelled organisms were lysed, and extracts were subjected to SDS gel electrophoresis and autoradiography.

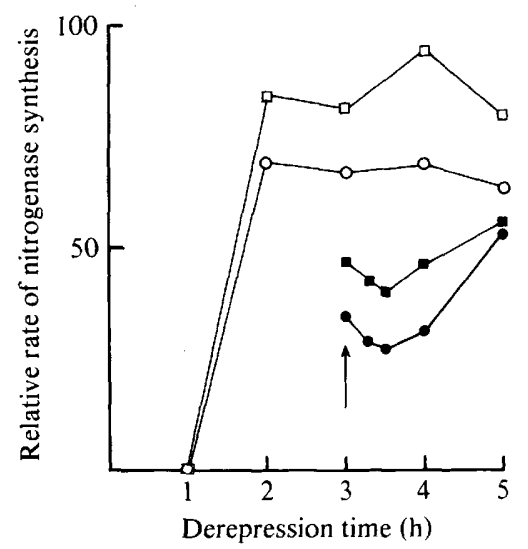

Fig. 4. Effect on nitrogenase synthesis of molybdate added to cultures of $K$. pneumoniae derepressed under conditions of Mo-deprivation. Nitrogenase synthesis was measured by scanning autoradiograms of SDS gels of extracts of labelled cells (see Methods). An $\mathrm{NH}_{4}^{+}$-repressed control culture was derepressed in the presence of molybdate $(100 \mu \mathrm{M})$ and samples were removed and pulse-labelled at various times of derepression: $\mathrm{O}, \mathrm{Kp} 1 ; \square, \mathrm{Kp} 2$. To a parallel suspension, derepressed under conditions of Mo-deprivation, molybdate was added at $3 \mathrm{~h}$ (indicated by the arrow) and at intervals samples were removed and pulse-labelled to assess the effect of molybdate on nitrogenase synthesis:, $\mathrm{Kp} 1$; $\mathbf{\square}, \mathrm{Kp} 2$.

\section{Effect of molybdate on the rate of expression of the nif structural genes}

The expression of operons in the nif gene cluster can be monitored from the levels of $\beta$-galactosidase activity in various nif-lac gene fusions (Dixon et al., 1980); during derepression the initial rate of expression of the nif structural genes was the same in the presence or absence of molybdate, but decreased after 3.5 to $4 \mathrm{~h}$ in the absence of molybdate.

The $\beta$-galactosidase activities were measured before and after the addition of molybdate to a merodiploid nif $^{+} /$nifH-lac fusion strain UNF619(pMF183), which showed normal derepression kinetics for nitrogenase activity in the presence of molybdate. After $4 \mathrm{~h}$ derepression of suspensions under Mo-deficient and Mo-sufficient conditions, molybdate was added to the Mo-deprived cells. In the $1 \mathrm{~h}$ following molybdate addition the specific activity of $\beta$-galactosidase in the Mo-deprived cells increased from 1223 to only $1541 \mathrm{nmol}$ $\min ^{-1}$ (mg protein) $)^{-1}$, compared with an increase from 1451 to $3733 \mathrm{nmol} \mathrm{min}^{-1}$ (mg protein $)^{-1}$ in the Mo-sufficient cells.

Substantial differences were also observed in the rates of synthesis of nitrogenase polypeptides in suspensions derepressed in the presence and absence of molybdate; 
tungstate $(100 \mu \mathrm{M})$ did not stimulate expression of nif genes (Fig. 3). There was no burst in the rate of synthesis when molybdate was added to Mo-deprived cultures (Fig. 4). No significant increase in the rate of expression occurred until $60 \mathrm{~min}$ after the addition of molybdate, during which time the specific activity of nitrogenase had increased at least six-fold (Fig. 2). These data indicate that the rapid effect of molybdate is not due to a rapid stimulation of expression of the nif structural genes.

\section{Effect of inhibitors of protein synthesis on reactivation by added molybdate}

Both chloramphenicol and tetracycline produced a $95 \%$ inhibition of protein synthesis within $30 \mathrm{~s}$ of addition to cultures, and neither stimulated nor inhibited the activity of preformed nitrogenase. Chloramphenicol, added $10 \mathrm{~min}$ before molybdate, usually completely prevented the stimulation of nitrogenase activity, although approximately $5 \%$ stimulation by molybdate was observed in some experiments. However, in the presence of tetracycline which inhibited protein synthesis equally effectively, a significant restoration of activity was observed (Fig. 2). Therefore, de novo protein synthesis was not required for rapid activation by molybdate and the process must involve activation of $\mathrm{Kp} 1$ apoprotein synthesized during Mo-deprivation.

Figure 2 also shows that the degree of activation increased with the duration of previous derepression under Mo-deprivation.

\section{Stability of nitrogenase polypeptides in Mo-deprived organisms}

The inability of cultures deprived of Mo for $16 \mathrm{~h}$ to respond rapidly to added molybdate, the very low levels of antigenic cross-reacting material, and the absence of nitrogenase polypeptides in extracts of such organisms on SDS gel electrophoresis, could be accounted for if the nitrogenase components synthesized early in the derepression period had been degraded. The stability of nitrogenase polypeptides under Mo-deprivation was therefore investigated by labelling derepressing cultures with ${ }^{14} \mathrm{C}$-labelled amino acids for $10 \mathrm{~min}$, inhibiting further protein synthesis by the addition of tetracycline or chloramphenicol, and monitoring the fate of labelled proteins by SDS gel electrophoresis and subsequent autoradiography.

When chloramphenicol was added after $4 \mathrm{~h}$ derepression, the bands corresponding to $\mathrm{Kp} 1$ polypeptides decreased in intensity with time. Degradation of $\mathrm{Kp} 1$ polypeptides occurred more rapidly in the absence of molybdate, and after $18 \mathrm{~h}$ they were barely detectable in extracts of Mo-deprived cultures. In contrast, $\mathrm{Kp} 2$ polypeptide was only slowly degraded in the presence or absence of molybdate. When tetracycline was used in place of chloramphenicol, the bands corresponding to the $\mathrm{Kp} 1$ and $\mathrm{Kp} 2$ polypeptides decreased in intensity during the $18 \mathrm{~h}$ following synthesis, although the extent of degradation was 2- to 3-fold lower than when chloramphenicol was used to inhibit protein synthesis.

\section{DISCUSSION}

In $K$. pneumoniae there are 17 genes in the nif cluster, the nifB, nif $N$ and nifE gene products being involved in molybdenum processing (Roberts et al., 1978). Studies using nif-lac gene fusions (Dixon et al., 1980) showed that the levels of expression of nifB, nifN and nifE are independent of added molybdate but that the nitrogenase operon nifHDKY is subject to autoregulation: maximum rates of expression require both molybdate and one or more polypeptides specified by that operon, although nitrogenase activity per se is not required. The requirement for molybdate for maximum rates of synthesis of nitrogenase polypeptides is further substantiated by our pulse-labelling data which show that after $3 \mathrm{~h}$ derepression synthesis is stimulated approximately two-fold by the addition of molybdate (Fig. 4). 
We have confirmed the observations of Brill et al. (1974) that only low levels of antigenic cross-reacting material to both nitrogenase components are found in $K$. pneumoniae after long derepression times and that, unlike $A$. vinelandii (Nagatani \& Brill, 1974), tungstate does not elevate levels of the MoFe protein. Since only very low levels of nitrogenase polypeptides could be detected by SDS gel electrophoresis, these data indicate that $\mathrm{Kp} 2$ and $\mathrm{Kp} 1$ apoprotein were not present at significant levels after prolonged Mo-deprivation, consistent with the failure of such cultures to respond rapidly to added molybdate.

The addition of molybdate to Mo-deprived cultures after short periods of derepression resulted in a biphasic restoration of nitrogenase activity. Because transcription and translation of the structural genes were not stimulated rapidly, we attribute the rapid tetracyclineinsensitive reactivation to activation of demolybdo- $\mathrm{Kp} 1$ protein, and the slower tetracyclinesensitive reactivation to the incorporation of added molybdate into newly synthesized $\mathrm{Kp} 1$ protein. Since the degree of tetracycline-insensitive reactivation increased with time in early derepression, and amounted to $60 \%$ of that of cultures derepressed in the presence of molybdate, the low levels of antigenic cross-reacting material detected (see Table 1) are surprising. We have no satisfactory explanation of this phenomenon. The low levels are unlikely to be due to weak reaction of antibody with demolybdo-Kp1 protein for several reasons. Firstly, Kpl purified from a nifB mutant of $K$. pneumoniae shows a strong antigenic reaction of identity with $\mathrm{Kp} 1$ antibody ( $\mathrm{T}$. Hawkes, personal communication); secondly, no change in the levels of cross-reacting material to $\mathrm{Kp} 1$ protein was observed in the $45 \mathrm{~min}$ following the addition of molybdate, during which time reactivation was complete; thirdly, low levels of cross-reacting material to both $\mathrm{Kp} 1$ and $\mathrm{Kp} 2$ proteins were observed under conditions of Mo-deprivation.

In suspensions supplied with molybdate throughout derepression, nitrogenase activities in vivo were comparable with the intrinsic activities measured in extracts (Table 1). However, the activity of $\mathrm{Kp} 1$ protein was only $37 \%$ of its maximum potential activity when assayed with an optimum excess of $\mathrm{Kp} 2$ protein (see Eady et al., 1972) indicating that levels of active $\mathrm{Kp} 2$ limit nitrogenase activity in these organisms. In contrast, under Mo-deprivation, $\mathrm{Kp} 1$ apoprotein levels decreased rapidly relative to $\mathrm{Kp} 2$ hence the ratio of $\mathrm{Kp} 2: \mathrm{Kp} 1$ increased and this may have caused the marked increase in nitrogenase activity when $\mathrm{Kp} 1$ was reactivated.

The factors which regulate intracellular protein degradation in the Enterobacteriaceae are complex (see Goldberg \& St John, 1976). Escherichia coli has two degradative systems, one which protects the cell from the accumulation of abnormal proteins, and a second inducible system which is activated on deprivation of a required nutrient (e.g. $\mathrm{NH}_{4}^{+}$) and whose activity is correlated with the intracellular levels of guanosine $3^{\prime}$-diphosphate $5^{\prime}$ diphosphate (ppGpp).

The apparent stability of $\mathrm{Kp} 2$ polypeptide under conditions of Mo-deprivation, when further synthesis was prevented by the addition of chloramphenicol or tetracycline after $4 \mathrm{~h}$ derepression, conflicts with the serological (Table 1) and SDS gel electrophoresis data which indicate that $\mathrm{Kp} 2$ cannot be detected after prolonged Mo-deprivation in the absence of inhibitors of protein synthesis. Since $\mathrm{Kp} 2$ polypeptide is unstable in the absence of $\mathrm{Kp} 1$ (Roberts \& Brill, 1980), and Kp1 polypeptides are degraded under prolonged Mo-deprivation, it seems that chloramphenicol and tetracycline inhibit the activation of, or prevent the synthesis of, a protease involved in degradation of $\mathrm{Kp} 2$ under these conditions. In contrast, the data for $\mathrm{Kp} 1$ are consistent with the apoprotein being degraded under conditions of Mo-deprivation, even in the presence of inhibitors of de novo protein synthesis, presumably because of an altered conformation which renders it susceptible to a different (constitutive) protease involved in degrading proteins with abnormal conformations (see Goldberg \& St John, 1976). The greater stability of $\mathrm{Kpl}$ polypeptides under both Mo-sufficient and Mo-deprived conditions when tetracycline was used in place of chloramphenicol to inhibit further protein synthesis may be a consequence of the rapid inhibition of ppGpp synthesis 
(and hence decreased proteolytic activity) by tetracyline (see Goldberg \& St John, 1976). It has been shown that during $\mathrm{NH}_{4}^{+}$-starvation of $K$ : pneumoniae, such as is required for the derepression of nitrogenase, the levels of ppGpp are elevated (Kleiner \& Phillips, 1981; D. Kahn, M. Hawkins \& R. Eady, unpublished).

Differences in the stability of the nitrogenase peptides under various conditions may also account for detection of $\mathrm{Kp} 1$ and $\mathrm{Kp} 2$ polypeptides in a narD mutant of $E$. coli carrying nif genes (Kennedy \& Postgate, 1977). In K. pneumoniae, as in both Plectonema boryanum (Nagatani \& Haselkorn, 1978) and Anabaena cylindrica (Hallenbeck \& Benemann, 1980), synthesis of protein de novo was not required for the restoration of activity by added Mo. However, in the latter organisms, unlike $K$. pneumoniae, restoration of activity occurred in the presence of chloramphenicol. The apparent requirement for protein synthesis for the restoration of activity by molybdate added to narD mutants of $E$. coli carrying $K$. pneumoniae nif genes (Kennedy \& Postgate, 1977) might well be a consequence of the use of chloramphenicol as an inhibitor of protein synthesis, since we have shown that chloramphenicol, but not tetracycline, inhibits the restoration in $K$. pneumoniae. Since chloramphenicol did not inhibit acetylene reduction in control cultures, it may exert a specific effect on molybdate uptake or processing, which makes it an unsuitable inhibitor for studies of this type in $K$. pneumoniae.

The provision of a long-term EMBO fellowship to D.K. is gratefully acknowledged. We thank Dr Ray Dixon for providing the nif-lac fusion strain UNF619(pMF183), Professor J. R. Postgate for constructive comments on the manuscript, and Dr. M. Iaccarino for useful discussion.

\section{REFERENCES}

Andersen, K., Shanmugam, K. T. \& Valentine, R. C. (1977). Nitrogen fixation (nif) regulatory mutants of Klebsiella: determination of the energy cost of nitrogen fixation in vivo. In Genetic Engineering for Nitrogen Fixation, pp. 95-110. Edited by A. Holleander. New York: Plenum Press.

BORTELS, H. (1930). Molybdän als Katalysator bei der biologischen Stickstoffbindung. Archiv für Mikrobiologie 1, 333-342.

Brill, W. J., Steiner, A. L. \& Shah, V. K. (1974). Effect of molybdenum starvation and tungsten on the synthesis of nitrogenase components in Klebsiella pneumoniae. Journal of Bacteriology 118, 986-989.

Cannon, F. C., Dixon, R. A., Postgate, J. R. \& Primrose, S. B. (1974). Chromosomal integration of nitrogen fixation genes in Escherichia coli. Journal of General Microbiology 80, 227-239.

Cardenas, J. \& Mortenson, L. E. (1975). Role of molybdenum in dinitrogen fixation by Clostridium pasteurianum. Journal of Bacteriology 123, 978984.

DIXON, R., EADY, R. R., EsPIN, G., HILL, S., IACCARINO, M., KAHN, D. \& MERRICK, M. (1980). Analysis of regulation of Klebsiella pneumoniae nitrogen fixation (nif) gene cluster with gene fusions. Nature, London 286, 128-132.

EADY, R. R. \& SMith, B. E. (1979). Physicochemical properties of nitrogenase and its components. In $A$ Treatise on Dinitrogen Fixation, sec. 1 \& 2, pp. 399-490. Edited by R. W. F. Hardy, F. Bottomley \& R. C. Burns. New York: Wiley.

Eady, R. R., Smith, B. E., Cook, K. A. \& Postgate, J. R. (1972). Nitrogenase of Klebsiella pneumoniae: purification and properties of the component proteins. Biochemical Journal 128, 655-675.

EADy, R. R., Issack, R., Kennedy, C., Postgate, J. R. \& RATClifFe, H. D. (1978). Nitrogenase synthesis in Klebsiella pneumoniae: comparison of ammonium and oxygen regulation. Journal of General Microbiology 104, 277-285.

Goldberg, A. L. \& ST JohN, A. C. (1976). Intracellular protein degradation in mammalian and bacterial cells. Annual Review of Biochemistry 44, 747-803.

Hallenbeck, P. C. \& BenemanN, J. R. (1980). Effect of molybdenum starvation and tungsten on the synthesis and activity of nitrogenase in Anabaena cylindrica. In Nitrogen Fixation (Enzymology, Physiology, Genetics): Applications in $\mathrm{H}_{2}$ and $\mathrm{NH}_{3}$ Production. Abstracts of a Société de Chimie Biologique/Commission of the European Community meeting on Nitrogen Fixation, Grenoble, June 1980 . Edited by P. M. Vignais.

Kelly, M. \& LANG, G. (1970). Evidence from Mössbauer spectroscopy for the role of iron in nitrogen fixation. Biochimica et biophysica acta 223, 86-104.

Kennedy, C. \& Postgate, J. R. (1977). Expression of Klebsiella pneumoniae nitrogen fixation genes in nitrate reductase mutants of Escherichia coli. Journal of General Microbiology 98, 551-557.

KENNEDY, C., EADY, R. R., KondorosI, E. \& ReKosh, D. (1976). The molybdenum-iron protein of Klebsiella pneumoniae nitrogenase. Evidence for non-identical subunits from peptide mapping. Biochemical Journal 155, 383-389.

Kleiner, D. \& Phillips, S. (1981). Relative levels of 
guanosine-3'-diphosphate-5' -diphosphate (ppGpp) in some $\mathrm{N}_{2}$-fixing bacteria during derepression and repression of nitrogenase. Archives of Microbiology 128, 341-342.

LAURELL, C. B. (1972). Electroimmuno assay. Scandinavian Journal of Clinical and Laboratory Investigation 124, 21-37.

NagataNi, H. H. \& BRILL, W. J. (1974). The effect of $\mathrm{Mo}, \mathrm{W}$ and $\mathrm{V}$ on the synthesis of nitrogenase components in Azotobacter vinelandii. Biochimica et biophysica acta 362, 160-166.

Nagatani, H. H. \& Haselkorn, R. (1978). Molybdenum independence of nitrogenase component synthesis in the non-heterocystous cyanobacterium Plectonema. Journal of Bacteriology 134, 597-605.

Postgate, J. R., Eady, R. R., Dixon, R. A., Hill, S., Kahn, D., Kennedy, C., Partridge, P., RobSON, R. \& YATES, M. G. (1981). Some aspects of the physiology of dinitrogen fixation. In Biological Metabolism of Inorganic Nitrogen and Sulphur Compounds, pp. 103-115. Edited by H. Bothe \&
A. Trebst. Berlin, Heidelberg \& New York: Springer,

Rennie, R. J., Funnell, A. \& SMith, B. E. (1978). Immunochemistry of nitrogenase as a probe for the enzyme mechanism. Evidence for multiple enzyme forms and an $\mathrm{MgATP}^{2-}$ binding site on the MoFe protein. FEBS Letters 91, 158-161.

Roberts, G. P. \& Brill, W. J. (1980). Gene product relationships of the nif regulon of Klebsiella pneumoniae. Journal of Bacteriology 144, 210-216.

Roberts, G. P., MacNeil, T., MacNeIl, D. \& BRILL, W. J. (1978). Regulation and characterisation of protein products encoded by the nif (nitrogen fixation) genes of Klebsiella pneumoniae. Journal of Bacteriology 136, 267-279.

RoBson, R. L. (1979). $\mathrm{O}_{2}$-repression of nitrogenase synthesis in Azotobacter chroococcum. FEMS Microbiology Letters 5, 259-262.

SPERL, G. T. \& DeMoss, J. A. (1975). chlD gene function in molybdate activation of nitrate reductase. Journal of Bacteriology 122, 1230-1238. 